\title{
Gaston Leval, Collectives in the Spanish Revolution, translated by Vernon Richards (Oakland: Freedom and PM Press, 2018). 416 pp. Paperback $\$ 27.95$ USD.
}

This classic is a book about the achievements of the "Spanish Revolution," an account of the popular collectivization of resources enabled by the breakout of the Spanish Civil war in July 1936. More specifically, Gaston Leval recounts his life in Spain during the "Revolution" and, drawing on interviews, ordinary peoples' lived experiences.

Gaston Leval (née Pierre Robert Piller) was born in Paris in 1895, radicalized to anarchism in his youth, and fled to Spain in 1915 to avoid conscription during the First World War. An anarchist, he collaborated with countless anarchist newspapers and soon he joined the anarcho-syndicalist National Confederation of Labour (CNT). He taught at the CNT-sponsored rationalist schools until 1923, when José Primo de Rivera's ascendant military dictatorship closed the schools and Leval and his wife fled for Latin America. Leval experienced little more than misery in his new home, and, in 1936, he returned to Spain upon news of the war to fight alongside the anarchists. Above all, his goal was to record and "promote by his propaganda the intensification and spread of [the collectivist] experiment to the preparation of which he had contributed for so long" (68). His end product, Collectives in the Spanish Revolution, explores the ways in which the socialization of property and the means of production encouraged socioeconomic successes and to the ability of communities to cooperate and organize for the common good. Drawing on both quantitative and qualitative data, he assesses those successes against their material, demographic, and intellectual background at the national but also at the transnational level. Moreover, Leval illustrates such achievements to a detailed degree both at the micro and macro level, describing isolated and local cases of collectivism as well as regionally coordinated ones.

However, Leval's politically-charged perspective (revealed by constant references to "our comrades," "our movement," “our adversaries," etc.) produces a story that fails to grasp the complexity of the conflict within which the "Revolution" took place. Above all, the Spanish Civil war is here portrayed as the event which allowed for the "Revolution" to happen, but little more than that. Actually, the conflict is largely depicted as essentially formed by counter-revolutionary forces. On the one hand, he describes Francisco Franco's troops as "the fascists," which is an oversimplification given that only a small section of the rebel troops, namely La Falange or Los Falangistas, were truly fascist. Moreover, this oversimplification seemingly 
leaves no room for any references to the vast military and financial support that Nazi Germany as well as Fascist Italy mobilized behind Franco's forces, inevitably losing sight of the international dimensions of the Spanish Civil war almost to the point of distortion. On the other hand, Leval talks about the "non-fascists." This generally refers to the Republican forces (socialists, republicans, and other leftist or center-left forces) and the Communists. As Leval sees it, the "fascist" and the "nonfascist" equally acted against the libertarian communists or collectivists, sabotaging their plans for the establishment of a "natural" structure (74-75).

From Leval's point of view, the Republic that preceded the war (and that followed Primo de Rivera's dictatorship) had been nothing but another version of the old, conservative, and bourgeois order which aimed solely at empowering the upper classes to the detriment of the lower classes. Evidently, he considers the Republic to have been a period of repression that undertook little to none of the reforms of which the people were in so much need. For example, Leval praises the educational accomplishments of the Collectives while claiming that under the Republican reform on education "only the children of the wealthy could afford ... education" (158), which is quite simply a historically inaccurate assertion. As a matter of fact, the Republic was a period of great educational achievement. During the first two years (Bienio Reformista), a republican-socialist coalition implemented a wide range of reforms such as the Escuelas Únicas and the Misiones Educativas, intended to make education available to all through free schooling and the establishment of coeducational schools in a unified, non-confessional system. Although such reforms were partly withheld by the conservative government in power from 1933 to 1936, the victory of the left-wing coalition Popular Front in February of that year enabled their continuation. Among the republican triumphs there are the construction of at least 6,500 new schools, the establishment of the first Department of Education, and the increase of the teachers' salary by up to 50 percent, just to name a few.

In terms of narrative, Leval presents and praises the mobilization of the anarchist forces as a separate party in the Republican effort against Franco. In doing so, he does not discuss the fact that the anarchist taste for military independence tended to debilitate the Republic, which struggled to keep its forces together against the rebels throughout the conflict. Instead, Leval argues that the Republic simply collapsed after the coup of July 1936, and that it was the collectivisations that "made it possible to hold out against [Franco] for nearly three years" (325). In this instance, as in the rest of the book, Leval disregards the undeniably crucial contributions of the Communists and the Soviet Union, which helped key Republican strongholds such as Madrid resist until the very end of the conflict. Nevertheless, Leval insists that Franco would have "triumphed in a matter of weeks" (325) if not for the anarchist "Revolution." Finally, he also regards the attempts of the anarchist CNT to collaborate with the Republic as a product of power "intoxication" and "indiscretion" (326) rather than as a product of cooperation. Although such an approach helps Leval reinforce his narrative "from below," it also undermines the role of the 
anarchist political leaders, thereby allowing the author to bypass the anarchist attempts to support rather than challenge the Republican forces in their effort against Franco.

Other imprecisions deserve attention. For example, although Leval by no means ignores the existence of women among the collectivists, he tends to deny them any revolutionary character and justify their less rewarded role within the "revolutionary" community. Illustratively, Leval points out that "most of the young girls [sic] were no paid specially to come and work here, since their basic needs were guaranteed by the family wage" (100). More inaccuracies include the constant reference to 19 July 1936 as the day Franco launched the coup against the Republic (e.g.: $58,70,76$ ), when in fact it was on the $18^{\text {th }}$ of that month. Lastly, there is also a notable linguistic misinterpretation that leads to the elaboration of a futile reasoning, namely translating the Spanish expression la bodega más rica del mundo, which refers to Spain as producing very fine wine, into meaning that Spain is rich in "underground resources" such as coal, iron, lead, zinc, mercury, silver, wolfram, and water (61). This misinterpretation leads Leval to use Spain's apparent lack of underground resources to explain the "natural cause of social poverty of the Spanish people [by] 1936" (62). Other inexactitudes are underscored by Stuart Christie and Pedro García-Guirao in the Preface and Introduction of this edition of Collectives in the Spanish Revolution (2018), which are largely explained by the context in which Leval wrote his book and his own personal political ideologies and role in the Spanish conflict.

Historical accuracy and impartiality do not, in my opinion, truly describe Collectives in the Spanish Revolution. In spite of this, Leval's account adds a priceless viewpoint to the history of the Spanish civil war, for the book is a product of the personal experience of an anarcho-syndicalist combatant. Its subjectivity should therefore be considered as an invaluable primary source revealing how the conflict was lived from and understood by the anarchist forces. Collectives in the Spanish "Revolution" will be particularly of interest to those who enjoyed George Orwell's Homage to Catalonia (1938), a first-hand account of fighting alongside the Republicans against Franco's forces, and other memoirs of the conflict such as The Face of War (1940) and Men in Battle (1957). For those interested in listening to more testimonies from those who took part in the "Spanish Revolution," I recommend watching the documentary film Vivir la Utopia or Living Utopia (1997), focused on the Spanish anarchist movement before and during the Spanish civil war.

Bàrbara Molas

York University 